\title{
Analisis Perbandingan Kualitas Website Peringkas Teks Otomatis Menggunakan Model ISO 9126
}

\author{
Witta Listiya Ningrum \\ Fakultas Ilmu Komputer Universitas Gunadarma \\ Jl. Margonda Raya No.100, Depok 16424, Jawa Barat \\ E-mail : wita_listiya@staff.gunadarma.ac.id
}

\begin{abstract}
Abstrak
Banyaknya dokumen teks yang tersedia, mengakibatkan terlalu banyak informasi yang dituntut untuk dapat diakses dengan cepat dan tidak membutuhkan banyak waktu dalam pengambilan intisari dari sebuah dokumen teks. Peringkas Teks Otomatis adalah salah satu solusi untuk membantu pencarian inti dari dokumen teks (Despande, 2013). Terdapat banyak parameter untuk mengukur kualitas suatu perangkat lunak. Parameter ISO 9126 merupakan salah satu standar yang sering digunakan sebagai dasar penilaian kualitas perangkat lunak secara umum, dikarenakan karakteristik pada model ISO 9126 lebih lengkap dibandingkan model kualitas perangkat lunak yang lain (Ferdiana, 2015). Penelitian ini bertujuan untuk memastikan apakah website tersebut memenuhi harapan dan tujuan pengguna dan untuk mendapatkan gambaran mengenai perbandingan kualitas website Peringkas Teks Otomatis.. Hasil dari penilaian tersebut didapatkan nilai 3.816 untuk website Tools4noobs dan 4.179 untuk website Smmry.

Kata kunci: ISO 9126, Peringkas Teks Otomatis, Website, Kualitas Perangkat Lunak
\end{abstract}

\section{Abstract}

There are more and more available text documents, which results in too much information being demanded to be accessed quickly and does not require much time to extract the essence of a text document. Automatic Teks Summarization is one of the solutions to help find the core of a text document (Despande, 2013). There are many parameters to measure the quality of a software. The ISO 9126 parameter is one of the standards that is often used as a basis for evaluating software quality in general, because the characteristics of the ISO 9126 model are more complete than other software quality models (Ferdiana, 2015). This study aims to ascertain whether the website meets the expectations and objectives of users and to get an overview of the quality comparisons of Automatic Teks Summarization websites. The results of the assessment obtained a value of 3,816 for the Tools4noobs website and 4,179 for the Smmry website.

Keywords: ISO 9126, Automatic Teks Summarization, Website, Software Quality

\section{PENDAHULUAN}

Banyaknya dokumen teks yang tersedia, mengakibatkan terlalu banyak informasi yang dituntut untuk dapat diakses dengan cepat dan tidak membutuhkan banyak waktu dalam pengambilan intisari yang dibutuhkan untuk mengambil keputusan. Menurut (Despande, 2013) Peringkas Teks Otomatis adalah salah satu solusi untuk membantu pencarian inti dari dokumen atau artikel berupa deskripsi singkat, sehingga pengguna dapat mendapatkan ringkasan dari sebuah tulisan dengan cepat tanpa harus membaca keseluruhan isi tulisan tersebut.

Penilaian terhadap website yang sudah ada perlu dilakukan supaya website memiliki kualitas yang baik. Penilaian ini bertujuan untuk mengukur tingkat fungsionalitas, kemanfaatan dan kemudahan akses pada sebuah website (Immomen, 2009). Penggunaan website untuk mendukung Peringkas Teks Otomatis terus berkembang sehingga diperlukan website yang berkualitas. Kualitas perangkat lunak dapat dinilai melalui ukuran-ukuran, 
metode-metode tertentu, serta melalui pengujian-pengujian perangkat lunak (Rizky, S. 2011).

Ada beberapa situs website Peringkas Teks Otomatis yang sudah ada, namun pasti terdapat kelebihan dan kekurangan dari masing-masing website tersebut. Parameter ISO 9126 merupakan salah satu standar yang sering digunakan sebagai dasar penilaian kualitas perangkat lunak secara umum, dikarenakan karakteristik pada model ISO 9126 lebih lengkap dibandingkan model kualitas perangkat lunak yang lain. Karakteristik terpenting dari model ISO adalah struktur hierarki, kriteria untuk melakukan evaluasi, dan sederhana (Behkamal, 2009). Dari pertimbangan tersebut, model ISO 9126 dipilih sebagai model kualitas yang akan digunakan dalam penelitian ini.

\section{METODE PENELITIAN}

Untuk menentukan sebuah kualitas perangkat lunak, penulis akan melakukan pengujian sebuah perangkat lunak dengan menggunakan model ISO 9126. Langkah - langkah yang akan dilakukan penulis dalam melakukan penelitian ini dapat dilihat pada gambar 1 dan gambar 2.

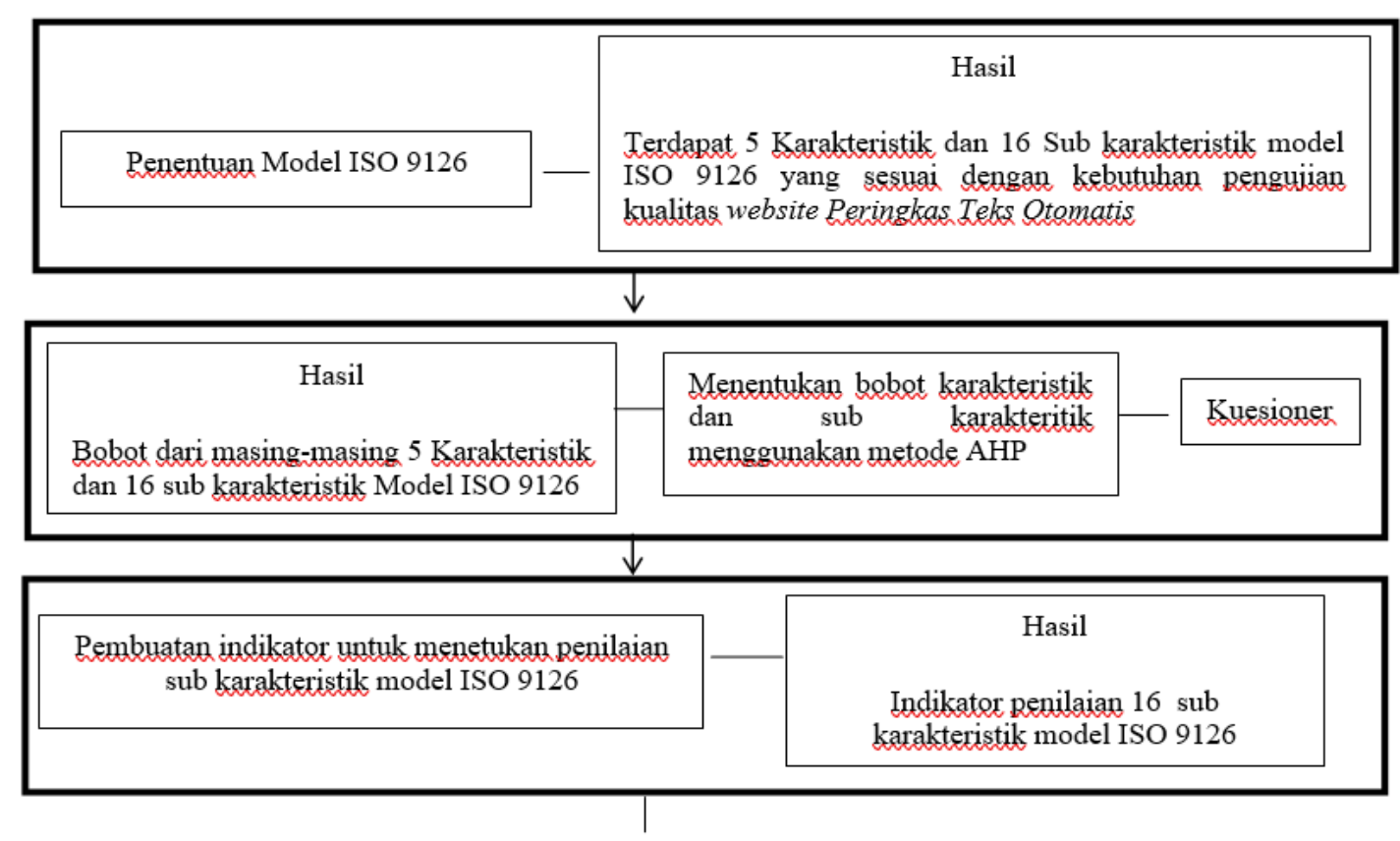

Gambar 1. Metode Penelitian (1) 
ISSN : $2356-5195$

Online ISSN: 2654 - 8704

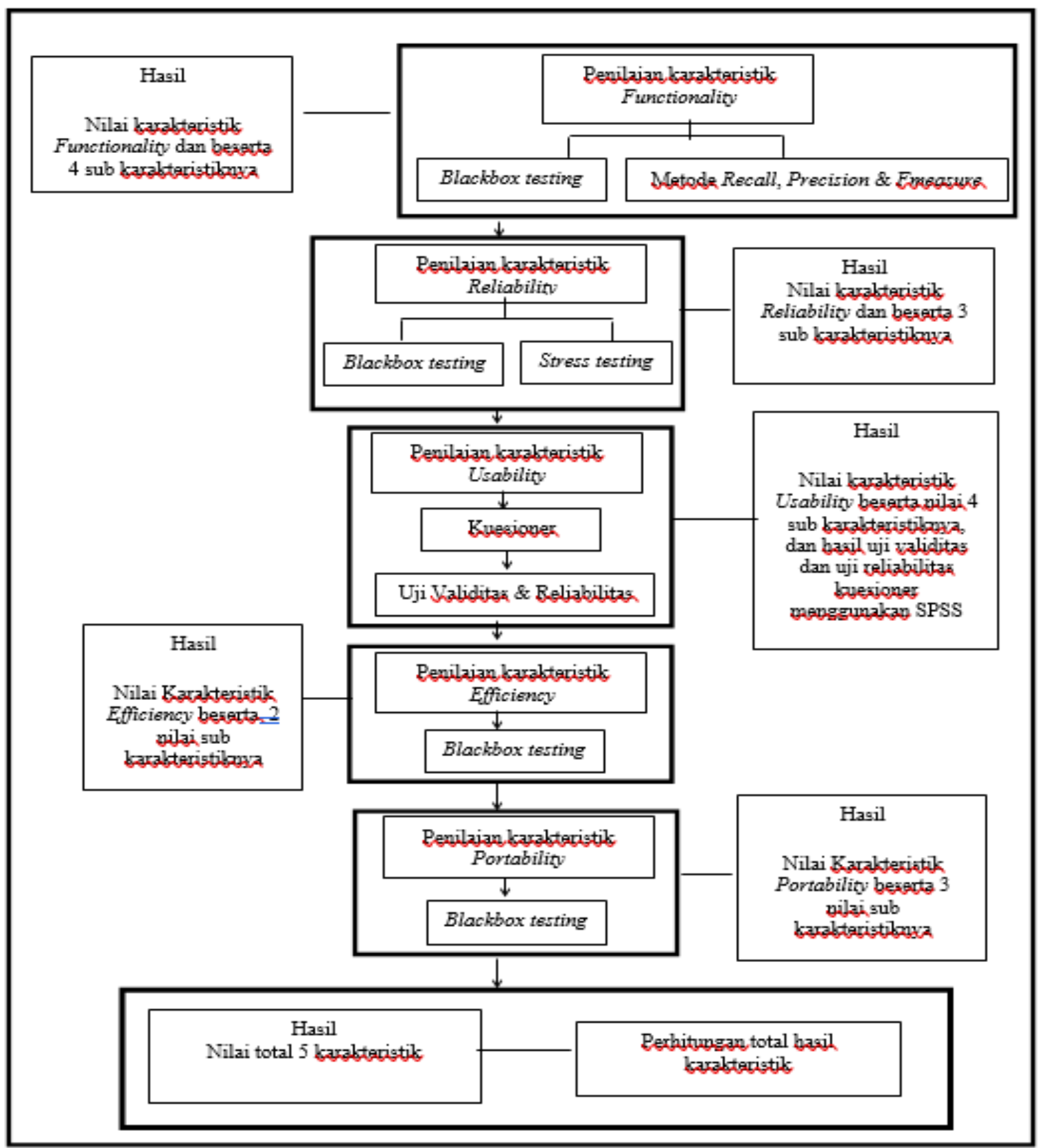

Gambar 2. Metode Penelitian (2)

\subsection{Penentuan model ISO 9126}

Pada langkah pertama dalam penelitian ini akan dilakukan penentuan terhadap model ISO 9126. Dari 6 Karakteristik terdapat 22 sub karakteristik pada model ISO 9126, sedangkan pada penelitian ini akan dilakukan penentuan terhadap karakteristik dan sub karakteristik, dimana pada penelitian ini hanya akan menggunakan 5 karakteristik dan 16 sub karakteristik model ISO 9126 (Hidayati, 2013). Alasan penulis tidak menggunakan semua sub karakteristik uji kualitas perangkat lunak model ISO 9126 karena ada beberapa sub karakteristik pengujian yang tidak dimiliki oleh website Peringkas Teks Otomatis yang akan diuji. Karakteristik dan sub karakteristik yang digunakan dapat dilihat pada gambar 3 . 


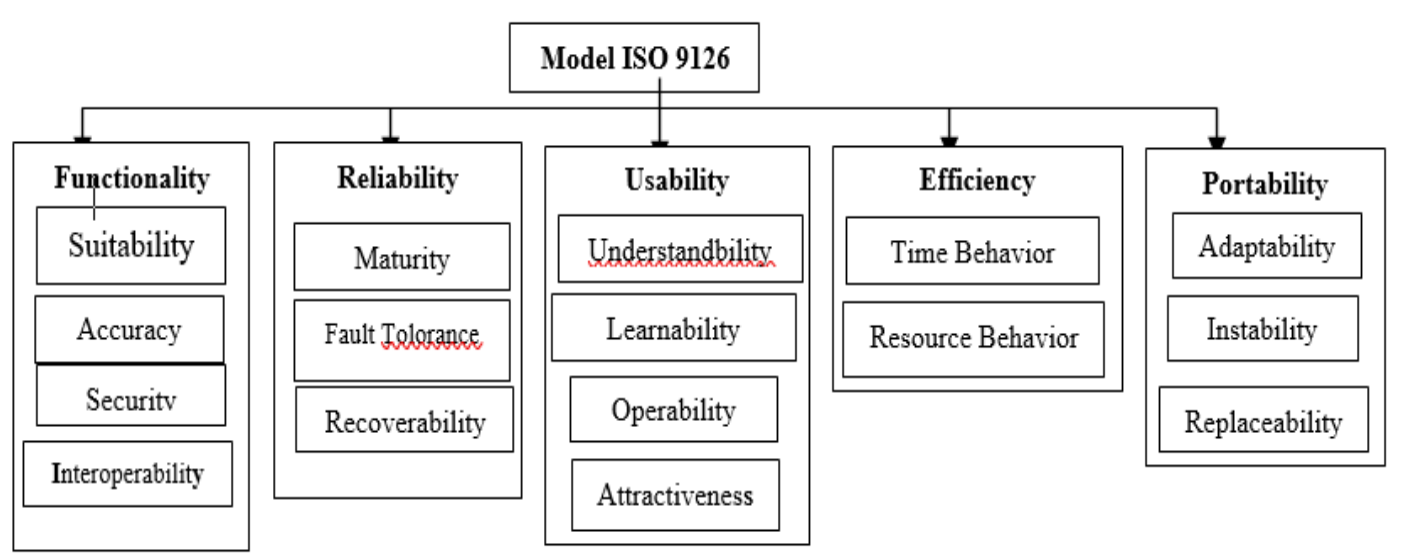

Gambar 3. Model ISO 9126

2.2 Penentuan Bobot Karakteristik dan Sub Karakteristik Menggunakan metode AHP

Pada tahap kedua dalam penelitian ini yaitu penentuan bobot karakteristik dan sub karakteristik menggunakan metode AHP. Penggunaan tools AHP adalah sebagai alat bantu perhitungan AHP, dan hasil yang dihasilkan tools ini juga cukup akurat, karena telah digunakan pada beberapa penelitian terdahulu (Saaty. 2000). Terdapat 5 Karakteristik dari model ISO 9126 yang digunakan oleh penulis, yaitu Functionality, Reliability, Usability, Efficiency, dan Portability. Langkah untuk menghitung bobot sub karakteristik sama dengan langkah untuk menghitung bobot karakteristik, yaitu menggunakan metode AHP.

\subsection{Pembuatan Indikator Nilai Sub Karakteristik Model ISO 9126}

Langkah selanjutnya yang akan penulis lakukan adalah melakukan penilaian kualitas Website Peringkas Teks Otomatis (tools4noobs dan smmry) sesuai dengan 5 karakteristik dan 16 sub karakteristik yang sudah menjadi standarisasi pada model ISO 9126. Masing-masing sub karakteristik memiliki kriteria penilaian yang berbeda - beda.

\subsection{Penilaian Karakteristik Model ISO 9126}

Model ISO 9126 yang digunakan oleh penulis pada penelitian ini, adalah menggunakan 5 karakteristik, yaitu Functionality, Reliability, Usability, Efficiency, dan Portability. Pada 5 karakteristik tersebut terdapat 16 sub karakteristik. Masing-masing karakteristik dilakukan penilaian berdasarkan Indikator yang telah dibuat berdasarkan masing-masing karakteristik.

\subsection{Hasil Penilaian Total Karakteristik}

Setelah melakukan tahap penilaian yang mengacu pada model ISO 9126, maka langkah selanjutnya yang akan dikerjakan adalah melakukan perhitungan berdasarkan bobot awal karakteristik dan sub karakteristik. Formula untuk menghitung hasil penilaian tersebut adalah sebagai berikut (McCall, 1977) :
$\mathrm{Fa}=\mathrm{w}_{1} \mathrm{c}_{1}+\mathrm{w}_{2} \mathrm{c}_{2}+\ldots+\mathrm{w}_{\mathrm{n}} \mathrm{c}_{\mathrm{n}}$
Dimana :
$\mathrm{Fa}=$ Nilai total dari faktor $\mathrm{a}$.
$\mathrm{w}_{\mathrm{i}} \quad=$ Bobot untuk kriteria $\mathrm{i}$.
$\mathrm{c}_{\mathrm{i}} \quad=$ Nilai untuk kriteria $\mathrm{i}$. 


\section{HASIL \& PEMBAHASAN}

Hasil dan pembahasan pada penelitian ini dibagi menjadi beberapa bagian sebagai berikut:

\subsection{Hasil Penentuan Bobot Karakteristik dan Sub Karakteristik Menggunakan Metode AHP}

Penentuan bobot ini menggunakan tools Analytical Hierarchy Process (AHP) berbasis web dengan url : http://bpmsg.com/academic/ahp_calc.php. Langkah pertama yang dilakukan untuk menentukan bobot karakteristik menggunakan metode AHP adalah menginput 5 karakteristik dari model ISO 9126. Setelah menentukan 5 karakteristik, maka langkah selanjutnya adalah menentukan prioritas dari 5 karakteristik yang akan ditentukan bobotnya. Untuk menentukan prioritas dengan cara memasukkan hasil kuesioner kedalam metode AHP, seperti pada tabel 2 .

Tabel 2. Jumlah Responden Kuesioner Karakteristik ISO 9126

\begin{tabular}{|c|c|c|c|c|c|c|c|c|c|c|}
\hline Pernyataan & 1 & 2 & 3 & 4 & 5 & 6 & 7 & 8 & 9 & 0 \\
\hline \multicolumn{11}{|c|}{$\begin{array}{l}\text { Menurut Anda, seberapa penting faktor Functionality pada sebuah website } \\
\text { terhadap faktor: }\end{array}$} \\
\hline Reliability (Kehandalan) & 7 & & 10 & 2 & 2 & & 5 & 3 & 1 & \\
\hline Usability (Kebergunaan) & 2 & 8 & 5 & & 4 & & 3 & 3 & 5 & \\
\hline Efficiency & 5 & & 9 & & 2 & 5 & 1 & 3 & 5 & \\
\hline Portability & 3 & & 6 & & 2 & 5 & 3 & 2 & 9 & \\
\hline \multicolumn{11}{|c|}{$\begin{array}{l}\text { Menurut Anda, seberapa penting faktor Reliability (Kehandalan) pada sebuah } \\
\text { website terhadap faktor: }\end{array}$} \\
\hline Usability (Kebergunaan) & 10 & 2 & 3 & & 5 & 3 & 7 & & & \\
\hline Efficiency & & 12 & 3 & 5 & 8 & 2 & & & & \\
\hline Portability & 7 & & 11 & 4 & 3 & & & 5 & & \\
\hline \multicolumn{11}{|c|}{$\begin{array}{l}\text { Menurut Anda, seberapa penting faktor Usability (Kebergunaan) pada sebuah } \\
\text { website terhadap faktor: }\end{array}$} \\
\hline Efficiency & 3 & 10 & 1 & 5 & 2 & 7 & 2 & & & \\
\hline Portability & & 5 & 4 & 5 & 2 & 9 & 1 & 1 & & 3 \\
\hline \multicolumn{11}{|c|}{$\begin{array}{l}\text { Menurut Anda, seberapa penting faktor Efficiency pada sebuah website } \\
\text { terhadap faktor: }\end{array}$} \\
\hline Portability & & 5 & 9 & 8 & 5 & & 2 & & 1 & \\
\hline
\end{tabular}

Setelah memasukkan hasil kuesioner kedalam metode AHP, dapat dilihat hasil pembobotan karakteristiknya seperti pada gambar 3 dibawah ini. 


\section{Priorities}

These are the resulting weights for the criteria based on your pairwise comparisons

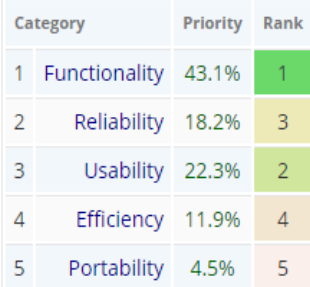

Number of comparisons $=10$ Consistency Ratio $\mathrm{CR}=1.6 \%$

\section{Decision Matrix}

The resulting weights are based on the principal eigenvector of the decision matrix

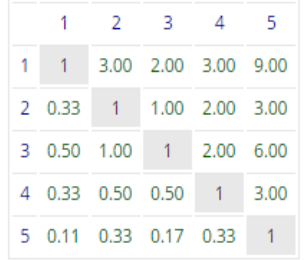

Principal eigen value $=5.071$

Eigenvector solution: 4 iterations, delta $=9.1 \mathrm{E}-9$

Gambar 4. Hasil Penentuan Bobot 5 Karakteristik

Setelah menentukan hasil penentuan bobot maka didapat nilai prioritas dari masingmasing karakteristik tersebut seperti dapat dilihat pada tabel 3.

Tabel 3. Hasil Hasil Penentuan Bobot Karakteristik dan Sub Karakteristik

\begin{tabular}{|c|c|c|c|c|c|}
\hline No & Karakteristik & $\begin{array}{c}\text { Bobot } \\
\text { Karakteristik }\end{array}$ & Sub Karakteristik & $\begin{array}{c}\text { Bobot Sub } \\
\text { karakteristik }\end{array}$ & Total \\
\hline \multirow[t]{4}{*}{1} & \multirow{4}{*}{ Functionality } & \multirow{4}{*}{$43.1 \%$} & Suitability & $30.8 \%$ & \multirow{4}{*}{$100 \%$} \\
\hline & & & Accuracy & $44.2 \%$ & \\
\hline & & & Security & $5.3 \%$ & \\
\hline & & & Interoperability & $19.7 \%$ & \\
\hline \multirow[t]{3}{*}{2} & \multirow{3}{*}{ Reliability } & \multirow{3}{*}{$18.2 \%$} & Maturity & $45.8 \%$ & \multirow{3}{*}{$100 \%$} \\
\hline & & & Fault Tolerance & $41.6 \%$ & \\
\hline & & & Recoverability & $12.6 \%$ & \\
\hline \multirow[t]{4}{*}{3} & \multirow{4}{*}{ Usability } & \multirow{4}{*}{$22.3 \%$} & Understandability & $37.9 \%$ & \multirow{4}{*}{$100 \%$} \\
\hline & & & Learnability & $32.3 \%$ & \\
\hline & & & Operability & $12.0 \%$ & \\
\hline & & & Attractiveness & $17.8 \%$ & \\
\hline \multirow[t]{2}{*}{4} & \multirow[t]{2}{*}{ Efficiency } & \multirow[t]{2}{*}{$11.9 \%$} & Time Behaviour & $66.7 \%$ & \multirow[b]{2}{*}{$100 \%$} \\
\hline & & & $\begin{array}{l}\text { Resource } \\
\text { Utilization }\end{array}$ & $33.3 \%$ & \\
\hline \multirow[t]{4}{*}{5} & \multirow{3}{*}{ Portability } & \multirow{3}{*}{$4.5 \%$} & Adaptability & $41.3 \%$ & \multirow[b]{3}{*}{$100 \%$} \\
\hline & & & Instability & $32.7 \%$ & \\
\hline & & & Replaceability & $26.0 \%$ & \\
\hline & & $100 \%$ & & & $100 \%$ \\
\hline
\end{tabular}

\subsection{Pembuatan Indikator Nilai Sub Karakteristik Model ISO 9126}

Setelah berhasil menentukan bobot karakteristik dan sub karakteristik dari model ISO 9126, maka langkah selanjutnya yang akan penulis lakukan adalah melakukan penilaian kualitas Website Peringkas Teks Otomatis. Pembuatan indikator nilai berbeda-beda pada setiap sub karakteristik, pada tabel 4 merupakan contoh indikator penilaian pada sub karakteristik Suitability. 
Tabel 4. Model Penilaian Sub Karakteristik Suitability

\begin{tabular}{|c|l|c|}
\hline Range & \multicolumn{1}{|c|}{ Kriteria } & Keterangan \\
\hline 1 & $\begin{array}{l}\text { Website Peringkas Teks Otomatis sama } \\
\text { sekali tidak bisa menyelesaikan tugas yang } \\
\text { mungkin diinginkan oleh user. }\end{array}$ & Sangat Buruk \\
\hline 2 & $\begin{array}{l}\text { Website Peringkas Teks Otomatis hanya } \\
\text { bisa melakukan salah satu dari banyak } \\
\text { tugas yang mungkin diinginkan oleh user. }\end{array}$ & Buruk \\
\hline 3 & $\begin{array}{l}\text { Website Peringkas Teks Otomatis dapat } \\
\text { menyelesaikan dua dari banyak tugas yang } \\
\text { mungkin diinginkan oleh user. }\end{array}$ & Cukup \\
\hline 4 & $\begin{array}{l}\text { Website Automatic Text Summarizatin } \\
\text { dapat menyelesaikan lebih dari dua tugas } \\
\text { dari banyak tugas yang mungkin } \\
\text { diinginkan oleh user. }\end{array}$ \\
\hline 5 & $\begin{array}{l}\text { Website Peringkas Teks Otomatis dapat } \\
\text { menyelesaikan semua tugas yang mungkin } \\
\text { diinginkan oleh user. }\end{array}$ & Sangat Baik \\
\hline
\end{tabular}

\subsection{Penilaian Karakteristik Model ISO 9126}

Setelah dilakukan penentuan bobot karakteristik dan pembuatan indikator, pada sub bab ini akan dilakukan pengujian dan penilaian terhadap kedua website Peringkas Teks Otomatis.

\subsubsection{Website Tools4noobs}

Tools4noobs merupakan sebuah aplikasi berbasis website untuk Peringkas Teks Otomatis atau peringkasan sebuah kalimat, dan merupakan website pertama dari dua website Peringkas Teks Otomatis yang akan dilakukan pengujian oleh penulis. Tahapan penilaiannya dilakukan dengan berbagai model testing yaitu melakukan pengujian black-box testing untuk pengujian karakteristik functionality, efficiency, dan portability. Metode Recall \& Precision untuk sub-karakteristik accuracy pada karakteristik functionality. Metode stress testing untuk pengujian karakteristik reliability, dan metode kuesioner J.R. Lewis untuk pengujian karakteristik usability terhadap 30 responden dari model ISO 9126.

\subsubsection{Pengujian Karakteristik Functionality}

Pada karakteristik functionality terdapat empat sub karakteristik yaitu suitability, accuracy, security, dan interoperability. Penilaian terhadap empat sub karakteristik tersebut menggunakan standar nilai yang sebelumnya sudah ditentukan. Penilaian terhadap sub karakteristik dari karakteristik Functionality dapat dilihat pada tabel 5.

Tabel 5. Total Nilai Functionality Tools4noobs

\begin{tabular}{|l|l|c|c|c|}
\hline NO & \multicolumn{1}{|c|}{ Sub Karakteristik } & Bobot & Nilai & Total \\
\hline 1 & Suitability & $30.8 \%(0.308)$ & 4 & $0.308 * 4=1.232$ \\
\hline 2 & Accuracy & $44.2 \%(0.442)$ & 4 & $0.442 * 4=1.768$ \\
\hline 3 & Security & $5.3 \%(0.053)$ & 4 & $0.053 * 4=0.212$ \\
\hline 4 & Interoperability & $19.7 \%(0.197)$ & 5 & $0.197 * 5=0.985$ \\
\hline \multicolumn{4}{|c|}{ Total $: 1.232+1.768+0.212+0.985=$} \\
\hline
\end{tabular}

\subsubsection{Pengujian Karakteristik Reliability}

Pada karakteristik reliability terdapat tiga sub karakteristik, yaitu sub karateristik maturity, fault tolerance, dan recoverability. Penilaian terhadap tiga sub karakteristik tersebut 
menggunakan standar nilai yang sebelumnya telah ditentukan. Penilaian terhadap sub karakteristik dari karakteristik Reliability dapat dilihat pada tabel 6.

Tabel 6. Total Nilai Reliability Tools4noobs

\begin{tabular}{|l|l|c|c|c|}
\hline NO & \multicolumn{1}{|c|}{ Sub Karakteristik } & Bobot & Nilai & Total \\
\hline 1 & Maturity & $45.8 \%(0.458)$ & 3 & $0.458 * 3=1.374$ \\
\hline 2 & Fault Tolerance & $41.6 \%(0.416)$ & 1 & $0.416^{*} 1=0.416$ \\
\hline 3 & Recoverability & $12.6 \%(0.126)$ & 3 & $0.126^{*} 3=0.378$ \\
\hline \multicolumn{4}{|c|}{ Total $: 1.374+0.416+0.378=$} \\
\hline
\end{tabular}

\subsubsection{Pengujian Karakteristik Usability}

Pada karakteristik usability terdapat empat sub karakteristik, yaitu sub karateristik understandability, learnability, operability dan attractiveness. Berdasarkan penilaian terhadap sub karakteristik dari karakteristik Usability, yaitu Understandability, Learnability, Operability, dan Attractiveness. Penilaian terhadap empat sub karakteristik tersebut menggunakan standar nilai yang sebelumnya telah ditentukan. Penilaian terhadap sub karakteristik dari karakteristik Usability dapat dilihat pada tabel 7.

Tabel 7. Total Nilai Usability Tools4noobs

\begin{tabular}{|l|l|c|c|c|}
\hline NO & \multicolumn{1}{|c|}{ Sub Karakteristik } & Bobot & Nilai & Total \\
\hline 1 & Understandability & $37.9 \%(0.379)$ & 4 & $0,379 * 4=1.516$ \\
\hline 2 & Learnability & $32.3 \%(0.323)$ & 3 & $0.323 * 3=0.969$ \\
\hline 3 & Operability & $12 \%(0.12)$ & 3 & $0,12 * 3=0.36$ \\
\hline 4 & Attractiveness & $17.8 \%(0.178)$ & 4 & $0,178 * 4=0.712$ \\
\hline \multicolumn{4}{|c|}{ Total $: 1.516+0.969+0.36+0.712=$} \\
\hline
\end{tabular}

\subsubsection{Pengujian Karakteristik Efficiency}

Pada karakteristik efficiency terdapat dua sub karakteristik, yaitu sub karateristik time behaviour, dan resource utilization. Penilaian terhadap dua sub karakteristik tersebut menggunakan standar nilai yang sebelumnya telah ditentukan. Penilaian terhadap sub karakteristik dari karakteristik efficiency dapat dilihat pada tabel 8.

Tabel 8. Total Nilai Efficiency Tools4noobs

\begin{tabular}{|l|l|l|c|c|}
\hline NO & Sub Karakteristik & Bobot & Nilai & Total \\
\hline 1 & Time Behaviour & $66.7 \%(0.667)$ & 5 & $0.667 * 5=3.335$ \\
\hline 2 & Resource Utilization & $33.3 \%(0.333)$ & 5 & $0.333 * 5=1.665$ \\
\hline \multicolumn{4}{|c|}{ Total : $3.335+1.665=$} & 5 \\
\hline
\end{tabular}

\subsubsection{Pengujian Karakteristik Portability}

Pada karakteristik portability terdapat tiga sub karakteristik, yaitu sub karateristik adaptability, instability, dan replaceability. Penilaian terhadap tiga sub karakteristik tersebut menggunakan standar nilai yang sebelumnya telah ditentukan. Penilaian terhadap sub karakteristik dari karakteristik portability dapat dilihat pada tabel 9.

Tabel 9. Total Nilai Portability Tools4noobs

\begin{tabular}{|l|l|c|c|c|}
\hline NO & \multicolumn{1}{|c|}{ Sub Karakteristik } & Bobot & Nilai & Total \\
\hline 1 & Adaptability & $41.3 \%(0.413)$ & 5 & $0,413 * 5=2.065$ \\
\hline 2 & Instability & $32.7 \%(0.327)$ & 5 & $0,327 * 5=1.635$ \\
\hline 3 & Replaceability & $26.0 \%(0.26)$ & 5 & $0.26 * 5=1.3$ \\
\hline \multicolumn{4}{|r|}{ Total $: 2.065+1.635+1.3=$} & 5 \\
\hline
\end{tabular}




\subsubsection{Website Smmry}

Smmry merupakan sebuah aplikasi berbasis website untuk Peringkas Teks Otomatis atau peringkasan sebuah kalimat, dan merupakan website kedua dari dua website Peringkas Teks Otomatis yang akan dilakukan pengujian oleh penulis.

\subsubsection{Pengujian Karakteristik Functionality}

Pada karakteristik functionality terdapat empat sub karakteristik yaitu suitability, accuracy, security, dan interoperability. Penilaian terhadap empat sub karakteristik tersebut menggunakan standar nilai yang sebelumnya sudah ditentukan. Penilaian terhadap sub karakteristik dari karakteristik Functionality dapat dilihat pada tabel 10.

Tabel 10. Total Nilai Functionality Smmry

\begin{tabular}{|l|l|c|c|c|}
\hline NO & \multicolumn{1}{|c|}{ Sub Karakteristik } & Bobot & Nilai & Total \\
\hline 1 & Suitability & $30.8 \%(0.308)$ & 5 & $0.308 * 5=1.54$ \\
\hline 2 & Accuracy & $44.2 \%(0.442)$ & 4 & $0.442 * 4=1.768$ \\
\hline 3 & Security & $5.3 \%(0.053)$ & 4 & $0.053 * 4=0.212$ \\
\hline 4 & Interoperability & $19.7 \%(0.197)$ & 1 & $0.197 * 1=0.197$ \\
\hline \multicolumn{4}{|c|}{ Total $: 1.54+1.768+0.212+0.197=$} \\
\hline
\end{tabular}

\subsubsection{Pengujian Karakteristik Reliability}

Pada karakteristik reliability terdapat tiga sub karakteristik, yaitu sub karateristik maturity, fault tolerance, dan recoverability. Penilaian terhadap tiga sub karakteristik tersebut menggunakan standar nilai yang sebelumnya telah ditentukan. Penilaian terhadap sub karakteristik dari karakteristik Reliability dapat dilihat pada tabel 11.

Tabel 11. Total Nilai Reliability Smmry

\begin{tabular}{|l|l|l|c|c|}
\hline NO & \multicolumn{1}{|c|}{ Sub Karakteristik } & Bobot & Nilai & Total \\
\hline 1 & Maturity & $45.8 \%(0.458)$ & 5 & $0.458 * 5=2.29$ \\
\hline 2 & Fault Tolerance & $41.6 \%(0.416)$ & 5 & $0.416 * 5=2.08$ \\
\hline 3 & Recoverability & $12.6 \%(0.126)$ & 3 & $0.126 * 3=0.378$ \\
\hline \multicolumn{2}{|c|}{ Total $: 2.29+2.08+0.378=$} \\
\hline
\end{tabular}

\subsubsection{Pengujian Karakteristik Usability}

Pada karakteristik usability terdapat empat sub karakteristik, yaitu sub karateristik understandability, learnability, operability dan attractiveness. Pengujian akan dilakukan dengan cara menyebar kuesioner terhadap responden. Berdasarkan penilaian terhadap sub karakteristik dari karakteristik Usability, yaitu Understandability, Learnability, Operability, dan Attractiveness. Penilaian terhadap empat sub karakteristik tersebut menggunakan standar nilai yang sebelumnya telah ditentukan. Penilaian terhadap sub karakteristik dari karakteristik Usability dapat dilihat pada tabel 12 .

Tabel 12. Total Nilai Usability Smmry

\begin{tabular}{|l|l|c|c|c|}
\hline NO & \multicolumn{1}{|c|}{ Sub Karakteristik } & Bobot & Nilai & Total \\
\hline 1 & Understandability & $37.9 \%(0.379)$ & 4 & $0,379 * 4=1.516$ \\
\hline 2 & Learnability & $32.3 \%(0.323)$ & 4 & $0.323 * 4=1.292$ \\
\hline 3 & Operability & $12 \%(0.12)$ & 4 & $0,12 * 4=0.48$ \\
\hline 4 & Attractiveness & $17.8 \%(0.178)$ & 4 & $0,178 * 4=0.712$ \\
\hline \multicolumn{4}{|c|}{ Total $: 1.516+1.292+0.48+0.712=$} \\
\hline
\end{tabular}

\subsubsection{Pengujian Karakteristik Efficiency}


Pada karakteristik efficiency terdapat dua sub karakteristik, yaitu sub karateristik time behaviour, dan resource utilization. Penilaian terhadap dua sub karakteristik tersebut menggunakan standar nilai yang sebelumnya telah ditentukan. Penilaian terhadap sub karakteristik dari karakteristik efficiency dapat dilihat pada tabel 13.

Tabel 13. Total Nilai Efficiency Smmry

\begin{tabular}{|l|l|l|c|c|}
\hline NO & \multicolumn{1}{|c|}{ Sub Karakteristik } & Bobot & Nilai & Total \\
\hline 1 & Time Behaviour & $66.7 \%(0.667)$ & 5 & $0.667 * 5=3.335$ \\
\hline 2 & Resource Utilization & $33.3 \%(0.333)$ & 5 & $0.333 * 5=1.665$ \\
\hline \multicolumn{4}{|c|}{ Total $: 3.335+1.665=$} & \\
\hline
\end{tabular}

\subsubsection{Pengujian Karakteristik Portability}

Pada karakteristik portability terdapat tiga sub karakteristik, yaitu sub karateristik adaptability, instability, dan replaceability. Penilaian terhadap tiga sub karakteristik tersebut menggunakan standar nilai yang sebelumnya telah ditentukan. Penilaian terhadap sub karakteristik dari karakteristik portability dapat dilihat pada tabel 14 .

Tabel 14. Total Nilai Portability Smmry

\begin{tabular}{|l|l|c|c|c|}
\hline NO & \multicolumn{1}{|c|}{ Sub Karakteristik } & Bobot & Nilai & Total \\
\hline 1 & Adaptability & $41.3 \%(0.413)$ & 5 & $0,413 * 5=2.065$ \\
\hline 2 & Instability & $32.7 \%(0.327)$ & 5 & $0,327 * 5=1.635$ \\
\hline 3 & Replaceability & $26.0 \%(0.26)$ & 5 & $0.26 * 5=1.3$ \\
\hline \multicolumn{2}{|r|}{ Total $: 2.065+1.635+1.3=$} & 5 \\
\hline
\end{tabular}

\subsubsection{Hasil Penilaian Website}

Setelah melakukan penilaian pada karakteristik dan sub karakteristik model ISO 9126 pada dua website Peringkas Teks Otomatis, akan dilakukan perhitungan total dari karakteristik dan sub karakteristik ISO 9126 pada dua website Peringkas Teks Otomatis tersebut. Dapat dilihat pada tabel 15 terdapat perhitungan total dari nilai karakteristik dan sub karakteristik website Peringkas Teks Otomatis Tools4noobs dan pada tabel 16 terdapat perhitungan total dari nilai karakteristik dan sub karakteristik website Peringkas Teks Otomatis Smmry.

Tabel 15. Total Nilai Tools4noobs

\begin{tabular}{|c|c|c|c|c|}
\hline NO & Karakteristik & Bobot & Nilai & Total \\
\hline 1 & Functionality & $43.1 \%(0.431)$ & 4.197 & $0.431 * 4.197=1.809$ \\
\hline 2 & Reliability & $18.2 \%(0.182)$ & 2.168 & $0.182 * 2.168=0.394$ \\
\hline 3 & Usability & $22.3 \%(0.223)$ & 3.557 & $0.223 * 3.557=0.793$ \\
\hline 4 & Efficiency & $11.9 \%(0.119)$ & 5 & $0.119 * 5=0.595$ \\
\hline 5 & Portability & $4.5 \%(0.045)$ & 5 & $0.045 * 5=0.225$ \\
\hline \multicolumn{4}{|c|}{ Total $: 1.809+0.394+0.793+0.595+0.225=$} & 3.816 \\
\hline
\end{tabular}

Tabel 16. Total Nilai Smmry

\begin{tabular}{|c|c|c|c|c|}
\hline NO & Karakteristik & Bobot & Nilai & Total \\
\hline 1 & Functionality & $43.1 \%(0.431)$ & 3.717 & $0.431 * 3.717=1.602$ \\
\hline 2 & Reliability & $18.2 \%(0.182)$ & 4.748 & $0.182 * 4.748=0.865$ \\
\hline 3 & Usability & $22.3 \%(0.223)$ & 4 & $0.223 * 4=0.892$ \\
\hline 4 & Efficiency & $11.9 \%(0.119)$ & 5 & $0.119 * 5=0.595$ \\
\hline 5 & Portability & $4.5 \%(0.045)$ & 5 & $0.045 * 5=0.225$ \\
\hline \multicolumn{4}{|c|}{ Total $: 1.602+0.865+0.892+0.595+0.225=$} \\
\hline
\end{tabular}




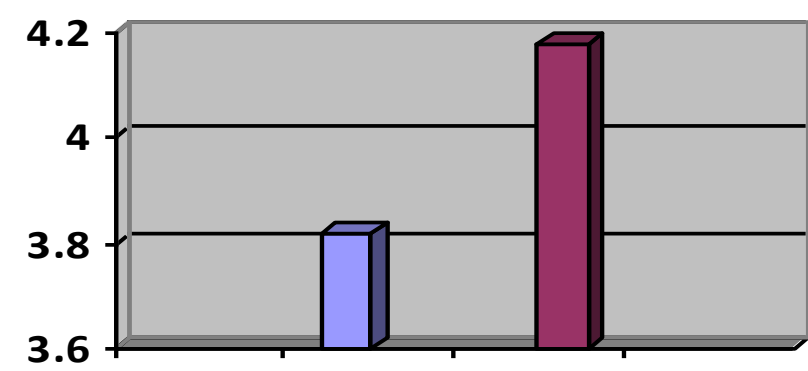

Gambar 5. Grafik Perbandingan Nilai Total Kedua Website

Setelah melakukan penilaian uji kualitas terhadap dua website Peringkas Teks Otomatis, yaitu Tools4noobs dan Smmry menggunakan metode ISO 9126 yang memiliki 5 karakteristik dan 16 sub karakteristik, Dari hasil penilaian tersebut didapatkan nilai 3.816 untuk website tools4noobs dan nilai 4.179 untuk website smmry.

\section{KESIMPULAN}

Hasil penilaian uji kualitas terhadap dua website Peringkas Teks Otomatis sudah berhasil dilakukan, yaitu website tools4noobs dan smmry menggunakan metode ISO 9126 yang telah dilakukan penyesuaian yang memiliki 5 karakteristik, dan 16 sub karakteristik. Dari hasil penilaian tersebut didapatkan nilai 3.816 dari nilai total 5 untuk website Peringkas Teks Otomatis Tools4noobs dan nilai 4.179 dari nilai total 5 untuk website Peringkas Teks Otomatis Smmry. Dengan adanya kedua website ini tentunya akan memberikan manfaat kepada para pengguna yang akan melakukan peringkasan sebuah artikel tanpa perlu membaca keseluruhan dari sebuah artikel dan tidak membutuhkan waktu yang lama untuk dapat mengetahui intisari dari sebuah artikel.

\section{SARAN}

Saran untuk kedua website Peringkas Teks Otomatis ini adalah agar dapat dilakukan perbaikan terfokus kepada karakteristik-karakteristik tertentu yang memiliki nilai kecil atau jauh dibelakang agar menghasilkan suatu website peringkasan yang lebih baik lagi.

\section{DAFTAR PUSTAKA}

[1] B. Behkamal, M. Kahani, M.K. Akbari, 2009, "Customizing ISO 9126 quality model for evaluation of B2B applications", Information and Software Technology, vol.51, March 2009, hlm. 599-609.

[2] Despande, A., L, Lobo., 2013, "Text Summarization using Clustering Technique", IJETT, Vol. 04, No. 08, Agustus 2013, hlm. 3348-3351.

[3] Ferdiana, S., Enggar, R., Laili, U., 2015, "Pengukuran Kualitas Website Berdasarkan ISO 9126 : Systematic Mapping”, Jurnal Manajemen Informatika, Vol. 04, No. 01, 2015, hlm. 26-35.

[4] Hidayati, Anita., Sarwosri., Ririd, Apriadi., 2013, Analisa Pengembangan Model Kualitas Berstruktur Hirarki Dengan Kustomisasi ISO 9126 Untuk Evaluasi Aplikasi Perangkat Lunak B2B. ITS.

[5] Immomen, Mika., 2009., Tieto Software Product Quality Analysis System. TAMK University of Applied Sciences.

[6] J.A. McCall, P.K. Richards, and G.F. Walters. 1977, Factors in Software Quality, Tehnical Report RADC-TR-77-369, US Department of Commerce.

[7] Thomas L, Saaty. 2000, "The Fundamentals of Decision Making and Priority Theory with the Analytic Hierarchy Process". RWS Publ., Vol. VI, 2000 (Revised). 